\title{
Zaman Kırıntıları Şiirinde Varlığı Tehdit Eden Unsur
}

\section{OĞUZ ÖCAL*}

\begin{abstract}
ÖZ
Ahmet Hamdi Tanpınar'ın Zaman Kırıntıları isimli şiiri, insan varlığını tehdit eden unsuru, esaret olarak görünüşe çıkaran bir şiirdir. Şiirde imlenen ve içinde olunan ancak çoğunlukla farkında olunmayan durumun ismi de olan esaret, en insanî olanakların ölümün belirlemesinde değerlendirilişi demektir. Olumsuz bir değerlendirmeyi içeren esaret, olanak açıcı yaşamın değil, bilakis olanak kapatıcı ölümün yaşamı belirlemesini bildirir. Aynı zamanda özgürlüğün yokluğunu da işaret eden esaret durumu, bu şiirde, ömrünün son dönemine girdiğini bilen şairin bir aşk ilişkisi esnasında karşılaştığı olanaklar arasından seçim yaparak yaşadı̆̆ı bir yitim deneyimi ile bu hadise karşısında aldığı tavırda ifadesini bulur. Bir diğer ifadeyle esaret durumu bu şiirde, bilme, duyma, görme, aşıp geçme, adama ve inanma gibi en temel olanakları kapatarak insan varlığını tehdit eden unsur olarak öne çıkarılır. $\mathrm{Bu}$ yazıda, öncelikle, özgürlük ve esaret kavramları kısaca tanımlanarak onların ölüm ve yaşam içgüdüleriyle ilişkisi ortaya konmuştur. Ardından da söz konusu şiir, bu esas iddiaya bağlı olarak özgürlük ile esaret kavramları bağlamında açımlanmıştır.
\end{abstract}

Anahtar Kelimeler: Ahmet Hamdi Tanpınar, Zaman Kirıntıları, Özgürlük, Esaret, Ölüm ve Kaçış

\section{ABSTRACT \\ The Threatening Factor to Existence in the Poem of Zaman Kirıntıları}

Ahmet Hamdi Tanpınar's poem named Zaman Kırıntıları is a poem which makes the factor threatening to human existence visible as the

* Doç. Dr. Kırıkkale Üniversitesi, Fen Edebiyat Fakültesi, Türk Dili ve Edebiyatı Bölümü, Kırıkale/Türkiye E-posta: ogzocal@yahoo.com

Makale Gönderim Tarihi: 31.10.2017 • Makale Kabul Tarihi: 20.04.2018 
captivity. The captivity which implies in the poem is the name of situation which exists inside but mostly not noticed. At the same time the captivity means to be evaluated the most personal human opportunities in determination of death. The captivity contains a negative evaluation and it states to determine the life of opportunity occlusive death, not the opportunity opener life. The captivity situation also states lack of freedom. In this poem, the poet who knows to be in the last term of own life lives a love relationship. During the love relationship he encounters the opportunities and chooses one of them and lives a loss experience. As a result the captivity concept shows up the poet's attitude againts this incident. In other words, in this poem the situation of captivity is highlighted as the factor threatening to human existence by closing the most basic opportunities such as knowing, hearing, seeing, overcoming, dedication and believing.

In this article, firstly, the concepts of freedom and captivity is shortly described. And it is proved that these described concepts' connection with the instincts of death and life. Then, the poem mentioned in this article is explained depending on this main claim in the context of the freedom and the captivity concepts.

Keywords: Ahmet Hamdi Tanpınar, Zaman Kirıntıları, Freedom, Captivity, Death and Escape

Q af şiirin edebiyatımızdaki güçlü isimlerinden birisi olan ve şiire kendisinin dişında herhangi bir görev yüklemeyen Ahmet Hamdi Tanpınar'ın serbest vezinle yazılan yoğun dokunmuş metinlerinden birisi de Zaman Kırıntı$\operatorname{ları}^{1}$ ismini taşır. Aynı zamanda şairin tamamlanmış şiirleri arasında içerdiği dize sayısı bakımından en uzun soluklu metni de olan Zaman Kirıntıları, insan varlığını tehdit eden unsuru, içinde olunan ancak farkında olunmayan esaret durumu olarak görünüşe çıkaran/1şıtan bir şiirdir. Bir diğer ifadeyle Zaman Kırıntıları, birbiriyle ölümcül gergin ilişki içinde olan ölüm ile yaşamın olanaklarını bünyesinde taşıyan insan varlığını tehdit eden unsuru, özgür olmayış olarak somutlayan bir metindir, diyebiliriz.

Felsefe tarihinin de çetin sorunlarından birisi olan esaret, öncelikle içinde olunan tinsel-psişik bir durumun ismidir ve farkında olunsun olunmasın, insanın en zatî olanaklarından birisi olan yaşamı, ölümün veya ölüm içgüdüsünün belirleyiciliğine bağlı olarak değerlendirmesi veya harcaması demektir. Daha iyi bir ifadeyle iç dünyası bu iki belirleyicinin üstünlük mücadelesine sahne olan insan varlığı için esaret, yaşamın değil, ölümün önde ve belirleyici olmasıdır. Esaretin ölüm ve ölüm içgüdüsüne bağlı olarak belirleyici olması durumunda, zorunlu olarak yaşam içgüdüsünün karşılığ1 olan özgürlük, be- 
lirleyiciliğini yitirmektedir². Bu durumda esaret, ölüm içgüdüsü ile gerçeklik ilkesinin, özgürlük ise yaşam ile haz ilkesinin birbirini karşıllklı olarak belirlemesidir. Az önce de belirtildiği gibi potansiyel olarak insan varoluşuna içkin olan bu iki olanak, gündelik varoluş içerisinde ancak ölümlü veya yitimli olduğuna dair geliştirilen bir bilinçle ve ona gösterilecek olan ihtimamla açı seçikliğe ulaşabilmektedir. Bu insana ait gerçeklik unutulduğunda ise olanaklar akış, gürültü ve ses yoğunluğuyla hesapçı tasarımcı zihniyetin hüküm sürdüğü bir dünyada unutulmaktadır.

Çerçevesini kısaca bu şekilde çizdiğimiz esaret durumu, belirleyici bir unsur olarak bu şiirde, ömrünün "akşam” vaktini yaşayan şairin genç bir kadınla karşılaştıktan sonra ortaya çıkan olanaklardan birisini tercih edip bir yitim deneyimi yaşaması ve bu deneyimle eş zamanlı olarak olanaklarını israf edişinde görünür hale gelir. Ve birbirini tamamlayan üç bölüm ile sunulur. Daha açık bir ifadeyle biz/ben ve sen zamirleri ile konuşan ve bir genç kızın örtülü şekilde ifade bulan "Benimle neden evlenmedin yahut senin için olanaklı olmama rağmen neden alışageldiğin yaşam şeklinde kaldın veya beni kendi halime bıraktın?" gibi bir sorusuna yine örtülü şekilde verilmiş bir cevabı da içeren bu şiir, herhangi bir işaretle belirtilmemiş olmasına rağmen, yitimin sonuçları, nedenleri ve yinelenen sonucunu ifade edebilecek şekilde üç bölüm olarak düşünülmüştür. Varsaydığımız birinci bölüm, şiirin açılış dizesinden "Bak martılar kanat çırpıyor sana" dizesine kadar olan kısmı kapsar ve esaretin neden olduğu yitim deneyiminin şairde ortaya çıkardığı duygu durumlarının görünümlerine ayrılmıştır. Yoğun öfke içeren bir psişik ve tinsel gerileyiş ile başlayan duygu durumu, kendilikten uzaklaşma ve inkâr aşamaları ile şiirin sonuna kadar dönüşerek devam edecek ve bir kayıtsızlıkta duraklayacaktır. İkinci bölüm, "Bak martılar kanat çırpıyor sana" dizesinden "Ne kadar uzak, uzak" dizesine kadar olan kısmı içerir ve yitimin nedenlerinin sıralanmasına tahsis edilmiştir. Üçüncü bölüm ise bu dizeden metnin sonuna kadar olan dizelerden oluşur ve yaşadığı yitimin nedeni ile sonucunun tamamen farkına varan şairin olanaklarıyla yeniden karşılaşıp felç edici yeni bir tercihte bulunmasının anlatılmasına ayrılmıştır. Daha açık bir ifadeyle birinci bölümde şair, esaretin bir varlık olarak belirleyip ortaya çıkardığı yitimin hem yasını tutar hem de sonuçlarını ortaya koyar. Ağırlıklı olarak lirik şiire uygun bir şekilde itirafları içeren bu ilk bölümün ardından şair, muhatap kişi olan genç kadına sen zamiriyle seslenerek ona olanaklarını bildirir ve aynı zamanda iltifat dolu sözlerinin satır aralarında ise yaşadığı bu yitim deneyiminin nedenlerini ortaya koyar. Son bölümde ise özgür olmayan şairin ortaya çıan yeni durum karşısındaki tavrı, yani varolanı kabullendiğini ifade eden yeni ve öncekini tekrarlayan bir seçimi, dramatize edilerek gösterilir. 


\section{Karşılaşma, Seçim ve Yitimle Açığa Çıkan}

"İnsan her eyleminde yeniden insan olmak veya insanlı̆̆ını her eyleminde var etmek durumunda olan bir karşılaşmalar süreci içindedir" (Çankaya 2012: 39).

Kısaca bu şekilde tanıttığımız Zaman Kırıntıları şiiri, esaret durumundaki anlatıcı öznesinin yaşadığını veya öyle olmasa bile kurgusal olarak deneyimlediğini düşündüğümüz, ancak metinde doğrudan ifade edilmeyen aşkını konu alan bir ön-hikâye üzerine kurulmuştur. Bu bir ön-anlama ile tercihi içeren hikâyenin tamamını tahmin etmek mümkün değildir; ancak metindeki esas belirleyici durum olan esaretin nedenleri ile sonuçlarının ifade edildiği bölümlerin satır aralarından hareketle bu hikâyenin ana çizgilerini şu şekilde ortaya koyabiliriz.

Metaforik bir ifadeyle ömrünün akşamına yaklaşan ve zaman çemberinin kapanmakta olduğunu bilen şair, yalnızlıkla örülmüş ve yapılandığı için kolay değişmeyecek birçok alışkanlıkları olan bir insandır. Gündelik tekrarlardan oluşan, yalnız ve çoğunlukla okuyup yazarak geçirdiği ömrünün sonlarına doğru şair, bir genç kadınla tanışır ve bu tanışıklık, şairin iç dünyasında yeni ümitler ile yeni bir birliktelik olanağının ortaya çıkmasına neden olur. Ortaya çıkan yeni durum, şairi, iki esas olanakla karşılaştırır: $O$, ya genç kadınla kısa veya uzun soluklu bir ilişki yaşayacak, belki onunla evlenecek ya da genç kadınla öyle bir ilişki kurmadan onu yitirecektir. Bir diğer ifadeyle şair, ya olagelen ve hiç memnun olmadığını bildiğimiz yaşamını tekrarlarıla birlikte olduğu gibi sürdürecek ya da onu değiştirerek devam edecek, yeni bir başlangıç yapacaktır. Bir yaşam şeklini muhafaza etme ile değiştirme veya onu olduğu gibi bırakma ile ona yeniden başlama gibi kendi bağlamı içerisinde düşünüldüğünde birisi olumlu diğeri olumsuz iki olanak arasında duran şair, metnin özellikle ikinci bölümünden çıkarabildiğimiz kadarılya olumlu olanı değil, olumsuzu tercih eder. Diğer bir ifadeyle şair, uzun süre yalnız kalmış olmanın getirdiği alışkanlıklarıyla ihtiyarlamı̧ ve geç kalmıs olduğuna inanması başka olmak üzere, ölüm içgüdüsünün açılımı olan bir esaret durumunda bulunduğu için, genç kadınla tanışmış olmanın beraberinde getirdiği bütün her şeye olmasa bile pek çok şeye yeniden başlama olanağını reddeder. Böylece de kendisini açılıkta tutmak yerine, bizzat kapalılık durumunda kalmayı yeğler ve ölüm içgüdüsünün emrinde bir olanağı harcayarak yitim deneyimi yaşar. Şüphesiz bu seçimle yitirilen sadece özgür olmanın karşıllı̆̆ olan yaşam veya yeni bir başlangıç olanağı değil, aynı zamanda şairin karşısına esaslı olarak belki de son kez çıkan değişerek devam etme veya varolan durumu aşıp geçmeyi de içerip taşıyan radikal yeni bir başlangı̣c yapma olană̆ıdır. Her 
seçim, ardı ardına önce bir yitimi, daha sonra ise bir durum olarak kendisini nedenleyenin ne olduğunu görünür hale getirir. Bunun için şairin yaşadığ 1 söz konusu yitim deneyimi, sadece basit bir kayıp olarak kalmaz; kendisinin ötesine geçerek bu deneyimi belirleyenin içinde olunan esaret durumu olduğunu da görünür kılar. Bir farkındalık halindeki bu bilgi ise şairi eş ve art zamanlı olarak önce yoğun bir değersizlik duygusunun aç1lımı olan çöküşe (depresyona), hemen ardından da derin bir yas durumuna (melankoliye) firlatır. Birbiriyle yer değiştirmesi olanak dâhilinde olan bu iki unsur, metinden takip ettiğimiz kadarıyla, yer değiştirerek varolur: Birisi öne çıktığında yoğun değersizleştirici bir tavırla neredeyse yok eder. Öteki kendisini gösterdiğinde ise yoğun onarıcı bir hüzünle açılan yarayı sarmaya, yıkılanı en az kayıpla kapatmaya çalı̧̧ır.

\section{Yitimin Nedenleri}

Pek çok şey, özellikle de kimi olanaklar, esas olarak değerini çoğunlukla yitimselliğinde açar. Pişmanlık başta olmak üzere hayal kırıklığ gibi pek çok durumun özünün kökeni de olan bu durum, yitimin esas olarak neliğinin farkına varıldığında açıcı, onun farkında olunmadığında ise kapatıcı olabilmektedir. Bir diğer ifadeyle duygu ile düşünce özlerini içeren durumların gerçekliği, kurtarıcı da ezici de olabilmektedir. Örneğin melankolinin belli bir aşamaya kadar yaşamın bir unsuru olarak açıcı, dolayısıyla da yapıcı ve onarıcı, belli bir aşamadan sonra ise ölümün açılımına dönüşerek kapatıcı, dolayısıyla da yıkıcı ve dağıtıcı bir unsur olması durumu gibi. Ya da en esas gerçeğini bildiğinde o durum kişiyi birçok tehlikeden koruyabilmekteyken aksi durumda ise gerçeklik ezici olabilmektedir. Aynı zamanda içinde olunan ancak farkında olunan veya olunmayan bir durumu da içeren yitim, hem bir durum tarafindan nedenlenir hem de o durumun görünür olmasını sağlar. Şiirde ise yaşadığı deneyimden sonra şair, ifadesini bulan itirafları ile pişmanlık ifadelerinden çıkarabildiğimiz kadarıyla, yitimin esas ve toplayıcı nedeninin şöhret olmak için kendisini tedricen biçimlendiren ve şeylere gerektiğinden fazla anlam veren bir insan olarak kendisi olduğunu anlar. Bu bakımdan şair, yitimin nedeni olarak esas olarak zamanı, dünyayı ve olanaklarını anlayıp yorumlayan bir varlık olarak kendisini öne çıkarır.

Şiirde görünür olduğu kadarıyla şairin yitim deneyimi yaşamasının nedenlerinden ilki, zamandır. Şair tarafından yorumlanan ve burada söz konusu olan zamanın, hem anlamsal ve değersel olarak bir tarihsel süreci hem de kendisini yitimsellikle görünüşe çıkaran bir fenomen olarak iki şekilde anlamlandırıldığını söylemek mümkündür. Bu iki boyuttan ilki olan anlamsal ve değersel boyutuyla zaman, seküler ve bireyci bir zihniyeti yaşatan modern çağı imler. 
Bilindiği gibi bu çăg, bireyin kendisini sınırlayan unsurlardan özgürleşip aklı ve iradesiyle hayatını şekillendirdiği bir zaman dilimi olarak öne çıkar. Para ekonomisi ile bireyciliğin birbirini karşılıklı olarak geliştirdiği bu zaman boyutunun en dikkat çekici özelliği ise sunduğu celp ve cezp edici olanaklarıla bireyi hem varoluşa teşvik etmesi, ona kendisinin yaratıcısı olabileceği cesaretini vermesi, hem de varoluşu seçen bireye biricik, özel ve önemli olmadığını bildirmesidir. Bireyi hem anlamlandırmaya teşvik eder hem de verilen anlamın boşluğunu yüzüne haykırır. Sadece bir örnek olması için son dönem fikir tarihimizin özü olan Doğu-Batı sentezini düşünerek diyebiliriz ki modern zaman, bireyi hem senteze davet ve teşvik eder hem de sürekli kendisini yenileyişiyle öyle bir sentezin olmasının olanaksız olduğunu gösterir ona.

Bu boyutuyla zaman, şiirde kendisini şaire eski bir sarayın kalıntıları arasında ilahlar kadar güzel bir genç kız şeklinde gösteren, ancak şair tarafından sahip olunmak istendiğinde elden kayıp giden bir varlık olarak imlenmiştir. Üst üste bindirilmiş anlamları içeren bu imgede yıkık sarayı, şairin yıkılışına şahit olduğu imparatorluğun, ilahlar kadar güzel genç kızı ise modern zamanın nesnel karşılığı olarak düşünmek mümkündür. Saray yıkılmış, yani genç kızın efendisi olan padişah (Tanrı'nın yeryüzündeki temsilcisi) ortadan kaybolmuş ve genç kız, yalnız kalmıştır. Yalnız ve efendisiz kalan genç kız, yani zaman, görünür olduğu şairi iki olanakla baş başa bırakmışıı: Şair ya efendisi olmak için onu ele geçirecek ya da onu kendi haline bırakacaktır. Ona sahip olmak, güce de sahip olmak olduğu için şairimiz birinci olanağı tercih etmiş, ancak teşvik edici olan zaman, bu eyleme karşlık kendi gerçeğini ortaya çıkarmış ve şairin iyelik isteğine karşı onun avuçlarından kurtulmak için çırpınmaya başlamıştır. Bu imgede dikkat edilirse modern zamanın insanı hem varoluşa teşvik ettiği hem de varoluşu elde tutmanın çok kolay olmadığını bildiren iki yönü birlikte öne çıkarılmı̧̧ıtır.

Ben zamanı gördüm,

Devrilmiş sütunları arasından

Çok eski bir sarayın

Alnında mor salkımlar vardı

Ve ilahlar kadar güzeldi.

Uçmak için kanatlanmayı bekleyen

Yavru kuş gibi doğduğu kayada

Ben zamanı gördüm

Çırpınırken avuçlarımda. 
$\mathrm{Bu}$ ilk boyutuyla teşvik edici olan zamanın ikinci boyutunda ise insana geçici, yani ölümlü olduğunu, dolayısıyla da biricik de özel de olmadığını anımsatan şevk kırıcı yönü bulunmaktadır. İlk boyutuyla büyüleyici, dolayısıyla olanak açıcı, hayal kurdurucu olan zamanın bu ikinci boyutuyla büyü bozucu ve yıkıc1, hatta insana ait gerçeği insanın yüzüne söyleyici olduğunu söyleyebiliriz. Her göstergenin hem gösterme hem de gizleme özelliği olduğunu düşünürsek bu boyutuyla zamanın da bir gösterge olarak öyle olduğunu söyleyebiliriz. Yani bu ikinci boyutuyla zaman, şiirde, kendisini sadece yitimsellik durumunda görünür kılan, diğer durumlarda ise kendisini gizleyen " $y 11-$ dırımsız ve baltasız", dolayısıyla sessiz çalışmasıyla bir ormanı yok edebilen bir hastalığa veya mezar kazıcısına benzetilir. Çok açık ki bu imgede insan ömrü, bir ormana benzetilmiş; ormandaki ağaçlar, ömrü oluşturan dakikalar, saatler ve günlerle eşleştirilmiştir. Akıp geçen zaman ise özellikle biyolojik ve psişik boyutlarıyla bu ormanı, sessiz sedasız tüketen bir yıkıcı unsur olarak düşünülmüştür. Her an gerçekleşen yitimiyle birlikte ormanı içinden çürütüp devirebilen zaman, aynı zamanda yiten giden anlarıyla parça parça ve sabırla bir mezarı da hazırlamaktadır. Sessiz sedasızlığıyla yıkıcı ve mezar kazıcı bir unsur olan zamanın bu yönü, ancak yitimselliğin farkında varıldığında, yani aydınlanma anının nesnel karşılığı olan şimşek aydınlığında kendisini göstermektedir. Diğger durumlarda ise kendisini tekrar gizleyip ormanı, ağaç ağaç yıkmaya; mezarı ise parça parça hazırlanmaya devam etmektedir.

Ben zamanı gördüm,

İçimde ve dışında sessiz çalışıyordu,

Bir mezar böyle kazılırdı ancak,

Yildırımsız ve baltasız,

Bir orman böyle devrilirdi!

Ben zamanı gördüm,

Kaç bakışta bozdu hayalimi,

Ve kaç düşüncede!

Ben zamanı gördüm,

Şimşek gibi bir anın uçurumunda.

Şairin işaret ettiği şekliyle yitimin ikinci nedeni ise teşvik edici ve bozucu iki yönü olan zaman gibi yine iki esas yönü olan dünyadır. Geçici bir süre de olsa içinde olunan bir yer olarak dünya, bir olanak ve aynı zamanda egemen varoluş modunun belirleyici olduğu bir varoluş alanıdır. Tek başına alındığında çok bir şey ifade etmeyen ancak egemen zihniyet ve oluş anlayışıyla birlikte 
düşünüldüğünde belirleyici bir unsur olduğu görünür olan dünya, geçmişten beri biçimlendirilmekte olan ve özellikle de modernite veya hesaplayıcı tasarlayıcı zihniyet tarafından yeniden şekillendirilen bir varoluş alanıdır. Niteliği modern olan ve hesapçı tasarımcı bir varoluşa imkân tanıyan egemen varoluş şekli, bireye hem kendisi, yani ne ise o olması için sayısız olanak sunar. Hem de birey kendisi olarak varolmaya çalı̧̧1dığında, yani şeyleri cümle cümle anlamlandırıp yorumlayarak varolduğunda ise hesapçı tasarımcı zihniyetinin kaba ve çiğ gerçekliğine ait farklı stratejileriyle kişiyi kendisinden şüpheye düşürene dönüşür. Onu önce hep olma veya ebedilik vaadiyle yoldan çıkarır, sonra ise hiçliğini duyurarak olduğu yere düşünür. Oyuna hem çağıran hem de oyunu bozan yanıyla dünya, şairi, zaman gibi önce olanaklarını değerlendirerek kendisi olarak varolmaya teşvik etmiş, ardından da gerçekliğiyle kendisinden şüpheye düşürmüştür. Şiirin ikinci bölümünde şair, hitap ettiği genç kadına varolan akışı bile tersine dönüştürebilecek, dolayısıyla da imkânsızı bile gerçekleştirebilecek bir potansiyeli olduğunu söylerken, bu iltifatın hem bir abartıyı içerdiğini hem de gerçeğini bildiği çift yönlü dünyaya olan tepkisini ifade ettiğini söyleyebiliriz. Bir diğer ifadeyle şair, genç kadını abartılı bir şekilde överken, iltifatların örtüsü altında, varolan şekliyle de güzel ancak güzelliği yetersiz olan şeyleri biçimlendiren hesapçı tasarımcı varoluşu hedefine koyar. Doğrudan bir ifade olmadığı için bu sözleriyle şair, aynı zamanda varolan dünyanın kendisi gibi hassas insanlar için itici ve orada kendisi olma ile insan kalmanın varolan akışa kendini bırakmakla değil, kökten bir dönüşüme bağlı olduğunu sezdirirken dünyanın bu çift içeriğini de ortaya çıkarmış olur.

Niçin sen yaratmadın bu dünyayı?

Ellerinin mesut işaretlerinden

Daha güzel doğardı eşya!

Daha zengin olurdu aydınlık

Kendi karanlığından çağırsaydı sesin,

Sular başka türlü akardı

Sert kayalardan göklere doğru

Büyük, mavi, aydınlık sular!

Birer belirleyici unsur da olan zaman ile dünyayı yukarıda da görüldüğü gibi çift içeriğiyle birlikte görüp değerlendiren şairin yitim deneyimini yaşamasının üçüncü ve en genel nedeni ise anlayıp yorumlayan bir varlık olarak bizzat kendisidir. Şiirin özellikle ikinci bölümünde, genç kadına yönelik uyarıcı nitelikli ifadelerinin satır aralarında şair hem genç kadına iltifat eder, uyarır 
onu hem de kendisinin şeyleri nasıl yorumladığını ortaya koyar. Bu bölümde şair, genç kadına hitap ederek, insanın olanak varlığı olarak rüya ile hayal, hayal ile hakikat, gece ile gündüz ve güneşle göz arasında yalnız kendisinin bulunduğu söyleyerek seçime, özgürlüğe ve sorumluluğa vurgu yapar. Narsisos mitine atıfta bulunarak ölümü imleyen kendisiyle çok meşgul olma durumunda olmaması, dolayısıyla da yaşamın olanaklarına kapalı kalmaması için uyarır genç kadını. Ayrıca ona kontrolü bizzat elinde tutması veya yaşamın akışına kendisini olduğu gibi bırakmaması gerektiğini hatırlatır. İlaveten gerçekleşmesi mümkün olabilen hayaller kurarak onlarla bütünleşmesini, ancak yaşam, yani güneş ile arasına imkânsızın parıltısını sokmamasını gerektiğini belirtir ve değişmenin sürekli olduğu yerde yaşamanın güzel olduğunu vurgular. İltifatlarla iç içe geçmiş bu uyarılar, tavsiyeler ve itiraflar, şairin şeyleri aslında nasıl yorumladı̆̆ını da açığa çıkarır aynı zamanda. Buradan çıkarabildiğimiz kadarıyla şair, varlığını yitimsellik üzerine değil, ondan kaçı̧̧ üzerine kurmuş; imkânlıyı değil, imkânsızı isteyerek kendisini ona göre ayarlamış; şeyleri bir kere kurduktan sonra onları hiç değiştirmemiş ve insanları gerçekten sevmemiştir. Bütün bu vakıalar ise toplu olarak yitimin en esaslı nedeninin olanakları anlayıp yorumlayan bir özne olarak şairin bizzat kendisi olduğunu ortaya çıkarır.

Eğilme sakın üstüne

Kendi yeşilinde boğulmuş havuzların,

Ve bırakma saçlarını tarasın rüzgâr,

Durmadan çukurlaşan bu aynada!

Bilinmez hangi uzaklara götürür seni

Dudak dudağa öpüştüğün hayâl!

Sokma güneşle arana,

İmkânsızın parıltısını!

Ve tanımdan, hiç tanışmadan sev insanları!

Değişmenin ebedî olduğu yerde

Güzeldir hayat!

\section{Yitimin Sonuçları}

Bu bir karşılaşmayı içeren ve ölüm içgüdüsüne esirliğin açılımı olan yitimle görünür hale gelen durumun birbirine bağlı pek çok sonucu olur. İçinde bulunduğu esaret durumunun esas nedeninin zamanı, dünyayı ve olanaklarını 
yorumlayan bir insan olarak bizzat kendisi olduğunu bilen şair, yaşadığı yitimin ardından eş zamanlı olarak hem derin bir çöküntü yaşar hem de derin bir kedere yakalanır. Yaşanan deneyim, şairi öncelikle yargılayıcı üstben'in baskısıyla o güne kadar tutunduğu kendilik değerlerinden koparır ve sıradanlık durumuna düşürür. Bir diğer ifadeyle kendisiyle karşılaşmaya ${ }^{3}$ çok vurgu yapan şairin bu metninde de gördüğümüz gibi kendisiyle karşılaşması, çok yıkıcı ve bir drama firlatıcı olmuştur. Öyle ki esir olduğunu anlayan şair ${ }^{4}$, kendisini önce acımasız bir şekilde zaman kırıntısına benzeterek değersizleştirir; zamanın üç boyutu arasındaki içten bağı kopardığını ve şimdi burada parçalanmış bir durumda olduğunu ortaya koyar. Bir parçalanmışlık durumunu imleyen kırıntı, aynı zamanda zamanın boyutlarını bütünleştirememiş olmayı da bildirir. Şair, değersiz bir kırıntı gibi gördüğü kendisini, ardından da iradesi olmayan seyircinin nesnel karşıllı̆ı olan bir sineğe benzeterek daha da değersizleştirir ve gerilediğini ortaya koyar. Kendine yönelik derin bir şiddeti de içeren bu imgedeki sineğin iskambil oyunlarının argo bir ifadeyle seyirci durumundaki kişilerini de işaret ettiğini bildirelim. Bir fail değil sadece seyirci, yani kaygılarına esir olduğunu sezen şair, bu farkındalığın firlatmasıyla yaşam denilen bu "aydınlık oyunun" kendisini de orada bulunmayı da lüzumsuz görür; kendisini de yaşamı da değersizleştirir. Eylemden kaçınan kişiye dünya denilen saf olanak, bütünüyle kendisini kapatır; şair gerilemeye devam eder ve iyileştirici özelliğinin olduğunu bildiğimiz anımsamanın bile işe yaramadığını ikrar eder. Kendisine karşı bu ifadelerin de gösterdiği gibi derin öfke duyan şair, doğumla başlayan ölümle kapanan sürecin metaforu olan zaman çemberinin kapanmakta olduğunu söyleyerek o güne kadar kendisini ayakta tutan değerleri kendi haline bırakarak bir boşluğa düşer. İçine düşülen boşluk, anlam, amaç ve nedenin yokluğu durumunu bildiren bir metafordur; yönünü kaybetme durumu da işaret eder. İnsan, anlamı ve amacı varken kendisini diğerlerinden ayırabilir. Bunlar olmadığında ise sadece kendisinden sorumluymuş, diğer şeylerden ve kişilerden sorumlu değilmiş gibi yapanlara benzer, s1radanlaşır. Yani şiirdeki ifadesiyle aynı tezgâhtan çıkmış testilere dönüşebilir. Bir başka ifadeyle verilen anlam, kişinin ötekilerle kendilik farkının oluşmasına neden olurken onun yokluğu ise bütün ayrılıkları kaldırır ve kişiyi onlarla eşitler. Bu boşluk duygusu içinde şair, kendisini ayrıca ipi kopmuş bir uçurtmaya benzetir. Bütün bu kırıntı, sinek, aynı tezgâhtan çıkmış testi ve ipi kopmuş uçurtma imlerinin ortak olarak da işaret ettiği gibi, yitimin nedeni olan ve aynı zamanda onunla birlikte açığa çıkan esaret durumu, zamanı, dünyayı ve olanaklarını yorumlayan bir insan olarak şairin bizzat kendisini değersizlik durumuna firlatır: 
Aynalar sonsuz boşluğa

Çoktan salıverdi çehremizi,

Yüzüyoruz,

İpi kopmuş uçurtmalar gibi.

Biz uzak seyircisi bu aydınlık oyunun,

Birden bire bulanlar içlerinde

Gülüncün sırrını,

İşte ne kadar benziyoruz şimdi,

Aynı tezgâhtan çıkmış testilere

Bir şey, bir şey kaldırdı bütün ayrılıkları!

Yitimin sonuçlarını bu şekilde deneyimleyen şair, suçlayıcı üstben'in değersizleştirmesinden sonra, kendisine karşı duyduğu öfkeyi derin bir yasa, ardından da bütün okurlarını reddeden bir tavra dönüştürür. Bir diğer ifadeyle şairin kendisine karşı duyduğu öfke, hüzünle çok kısa bir an için örtüldükten sonra, son derece hızlı bir şekilde kapsamı genişleyen bir şiddete dönüşür.

Kim tanır bizi şimden sonra,

Aydınlı̆̆ kıt gecemize

Misafir olanlardan başka;

Kuru tahta üstünde bizimle

Paylaşanlar günlerimizi

Ve benim gözlerimle bakanlar güneşe

Ancak tanır bizi

Mor çemberlerin uçuştuğu akşam sularından?

Akşamın tek bir ağaç gibi

Dal budak saldığı sular

Çocukluk rüyâlarının bahçesi!

Sakın kimse el sürmesin dallara,

Yapraklar, meyvalar olduğu gibi kalsın

Benim uykum boyunca!

Alıntılanan metnin açılış dizesinde şair, o güne kadar peşinden koştuğu tanınma isteğinin tükendiğini ve üstelik bu haliyle de kimsenin kendisine değer vermeyeceğini belirterek o güne kadar olmakta olanın esas olarak bir özgürlük değil, esaret durumu olduğunu ortaya koyar. Hakikaten meşhur olmaya düşkünlüğüyle de bilinen şairin bu durumu, mektuplarında ve günlüklerinden 
de bildiğimiz kadarıyla çok istenilen bir şeyin yitimi demektir 5 . Şair hüsrana uğramış olmasına rağmen yine de anlaşılma ve tanınma isteğinin gerçekleşmesinden umutludur, ancak bu isteğinin gerçekleşebilmesi için artık ayrım yapmaktadır: Bundan sonra kendisini herkes değil, sadece "aydınlığı kıt gece"sine misafir olanlar, yani kendisiyle bir şeyleri paylaşanlar anlayabilecektir. Ne var ki bu umut şairde çok kısa bir süre canlı kalır. Devam eden dizelerde gerçekliği, yani kendisine o güne kadar gösterilen kayıtsızlığı anımsayarak hızla gelip geçen derin bir sitemle hüzünden sonra, en az onlar kadar güçlü bir öfkeye kapilır. Ve çöküşün rengi olan mor çemberlerin uçuştuğu bu akşam saatinde yani ihtiyarlık zamanını takip edecek uyku yani ölüm hadisesinden sonra, bu ihtiyar ağacın yani kendisinin yapraklarına ve meyvalarına, yani eserlerine kimsenin dokunmamasını gerektiğini söyler. Böylece yaşarken kendisine ilgisiz kalan insanları adeta reddeder.

Okur kitlesini toptan reddedip kendisi gibi eşsiz bir sanatçının şartlı anlaş1labileceğine dikkati çeken şair, bu açık reddiyeyi içeren bu hissî tavrını, genç kadına olanaklarını işaret ederken bir süreliğine paranteze alır. Bu bilinçli ara veriş, genç kadına yönelik iltifatların ve onun şahsında yaşamı olumlamasının ardından şairin olumsuz tavrını yumuşatır ve şairin öfkesi, hüzne veya çaresizliğe dönüşür. Ne var ki mutsuz olduğunu, yani sevinçlerin kendisine bir yabancı gibi uzaktan geldiğini ve içinde hüznün çiçek açtığını, yani sürekli kendisini yeniden ürettiğini fark edince bu duygu durumu yeniden değişir. Kendisiyle bir kere daha karşılaşan şair, öfkeyi de hüznü de değersizleştirircesine "Ne çıkar unuttuk hepsini!" cümlesinin işaret ettiğgi geniş bir kayıtsızlığa ulaşır. Bu kayıtsızlık ifadesi, sevilen genç kadın adına bilinçli olarak paranteze alınıp bastırılan öfkenin ikinci bölümü oluşturan iltifatlardan sonra parantezin dışına taşarak yıkıcı bir şekilde geri döndüğünü işaret eder. Şüphesiz bastırıldığı için dışarıdan içeriye geçildikçe öfkeden hüzne dönüşen bu durumun kayıtsızlıkla neticelenerek başladığı noktaya dönmesi, içinde olunan ancak farkında olunmayan esaret durumunun şairi belirlediğini görünür kılar. Buradan ileri giderek şairin bu belirleyiciyi bizzat onayladığını da ortaya koyar.

Ne kadar uzak, uzak

Yollardan gelir bize

Ve çok yabancı bir şey gibi sevinçlerimiz,

Keder durmadan çiçek açar içimizde.

Ne çıkar unuttuk hepsini! 


\section{Yeniden Seçim ve Alınan Olumsuz Tavır: Tecahül-i Arif}

Martin Heidegger, insan varlığının anlamı, amacı ve nedenini yitimsellik durumunu işaret eden zamansallık, dolayısıyla da tarihsellik olduğunu söyler ve en temel insanî olanak olarak da işaret ettiği yitimselliğe dayalı yorumlamay1 sahih varoluş şekli, yitimselliği unutarak varoluşu ise gayrisahih varoluş biçimi olarak niteler. Ona göre bu iki varoluş şeklinin en önemli özelliği ise açıklık ve kapalılıktır. Sahih varoluş, ölüm veya yitim farkındalığı üzerine kurulduğu için açıcı, diğeri ölümü unutma durumunu imlediği için kapatıcıdır. İlki hakikîdir, çünkü en hakikî olan doğum ile ölüm gerçeği üzerine kurulmuştur, diğeri ise bu esas gerçeklik üzerine değil, ondan kaçı̧ ve yorum üzerine kurulduğu için hakikî değildir. İlki, açıcı olduğu için doğruluğu veya kendini kandırmamayı gerekli kılarken ikincisinde ise kendini kandırma söz konusudur (Heidegger 2008: 43-244).

Bu bağlamda şiire bakarsak, yitimin nedenleri ile sonuçları tamamen açığa çıktıktan sonra şair, farkına vardığı durumun açtı̆̆ hem daha öncekini yineleyen hem de niteliği bakımından yeni olan iki olanakla karşılaştırır. O, ya açı̆̆a çıkışıyla esaretin görünür bir hale gelmesine neden olan yitimselliğine sahip çıkarak kendisi için sahih yeni bir başlangıç yapacak, dolayısıyla ölüm içgüdüsünü yaşamın denetiminde tutacak ya da varolan esaret durumunu, olduğu gibi bırakarak daha kötü bir duruma düşecektir. Sınır durumdaki şair, başlangıçtaki dolaylı ifade edilen seçiminde olduğu gibi, bu son karşılaşmadan sonra da yaşamın açılımı olan özgürlügü değil, ölümün aç1ımı olan esaret durumunda kalmayı yeğler. Bir diğer ifadeyle şair, "boş yere gerilmişiz" ve "boşuna sızlamış kemiklerimiz" ifadelerinin taşıdığı çok derin bir pişmanlık duygusu ile istifham sanatının eşliğinde "beyhude yere gecik"tiğini ikrar eder. $\mathrm{Bu}$ ikrarın hemen ardından da yitimselliğin açıklığını değil, esaretin kapalılığını tercih ederek neredeyse bütün bir son bölüme hâkim olan tecahül-i arif sanatının da işaret ettiği gibi, geniş bir gayrı sahih durumda kalmayı seçer. Bu bakımdan şairin yaşamının son dönemine girmiş olması başta olmak üzere, imkânlı ile imkânsız arasında geçmişte bir tercih yapıp şimdi burada yaptı̆̆ı seçimden dolayı yanıldığını itiraf etmesi, sadece bir günah çıkarma olarak düşünebilir, ancak bu son seçimi konusunda onu mazur görmemize neden olamaz elbette. Çünkü seçim, her yer ve zamanda seçimdir ve zorunlu olarak değerlerin değerlemesini içerdiği için özgürlüğü işaret eder ve insanı sorumlu tutar. Ölüm gibi devredilemez bir unsur olan özgürlük, insan varlığının ölüm hadisesi gerçekleşene kadar koşulsuz sürekli yeniden değerlendirmek zorunda olduğu bir anlam, amaç ve neden kaynağıdır. Sahih varoluş onu değerlen- 
direrek açıklığa, gayrısahih olan ise kapalılı̆ga koyar.

Biz ki boş yere gerilmişiz anladık artık,

Yıldızların amansız çarkına

Ve boş yere sızlamı̧̧ kemiklerimiz,

Bilmiyoruz şimdi, mevsim yaz mı, bahar mı,

Bahçelerde hâlâ güller açar mı,

Şarkılar, masallar var mı?

Gece ile gündüz,

Acıdan kaskatı kesilmiş yüz,

Uykusuzluktan harap göz,

Öpüşen dudaklar,

Çözülmeye razı olmayan eller var mı?

Ayrilik var mı gurbet var mı?

Biz beyhude yere gecikenler,

Çoktan bitmiş bir yolun ucunda

Bilmiyoruz şimdi ıssız gecede

Ne yapar ne eder,

Gidip de gelmeyenler,

Beyhude bekleyenler!

Biz ayın çıplak arsasında

Savrulan zaman kırıntıları,

Nereden bilelim bunları!

\section{Varlığı Tehdit Eden Unsur}

Yaşadığ dönemde çevresinde saygı gören ancak ondan tatmin olmayan şairin beklediği ilgi, bilindiği gibi ölümünden sonra gelmiş ve bu da şairin simgesel yeniden doğumu olmuştur. "Kimileri öldükten sonra yeniden doğar" (Nietzsche'den alıntılayan Kaufmann 2009: 28). Bu son derece özel hadisenin "şeyler değerini yitimsellikle açar" düşüncesiyle yorumlandığında bağlamını bulduğunu ve esas olarak "ölü severlikle" bir alakasının olmadığını belirtip ölümünden sonra meşhur olan şairin istisna nitelikli olanların dışındaki pek çok metninde Haluk Sunat'ın da gözlemlediği gibi, ölüm isteğinin ifadesini bulduğunu söyleyebiliriz (Sunat 2014: 295-320). Bu yazıda açımlanan $\mathrm{Za}$ man Kırıntıları şiiri de ölüm takıntılı şairin aslında bir tehlikeyi dramatize ederek gösteren metni olarak diğer metinleriyle buluşur. 
Şiirde dramatize edilerek görünüşe çıkarılan ve insan varlığ için tehdit olan unsur, esarettir. İçinde olunan ancak farkında olunmayan bir durum olarak esaret, yukarıda da ifade ettiğimiz gibi şiirde ifade bulan her şeyi belirler ve her şeyde görünüşe çıkar. Öyle ki şiirin üç bölümünü oluşturan seçimler, esareti imlediği gibi, şairin itirafları ile iltifatları da bu hususu açığa çıkarır. Ayrıca şiirde öfke ve yas ile başlayıp reddiyeye ulaşan ve kayıtsızlıkta duraklayan haleti ruhiye ile şiirin sonunda görünüşe çıkan kayıtsızlık ifadesi de bu durumu ayrı ayrı somutlar. Özellikle ikinci bölümde görmüş geçirmiş şairin olanakların sınırında duran genç kadına verdiği bilgece nasihatler ile onu yaşama doğru teşviki, ilk bakışta özgürlük gibi göründüğü için esaret durumunu geçersizleştirmektedir. Ancak bir bütün olarak düşünüldüğünde bu durum, ihtimam göstermenin ilk, yani kendine ihtimam gösterme uğrağını pas geçtiği için sahih değil, gayrısahih bir ihtimam gösterme veya itina etmedir. Bu yönüyle de ayrıca kendini kandırmayı ve kendinden kaçı̧ı, dolayısıyla da esaret durumunu imler. Az önce de belirttiğimiz gibi, o bölüme biraz daha yakından bakı1dığında, şairin esas derdinin olanaklarını işaret ederek genç kadına varlı̆̆ını tehdit eden unsurları göstermek değil, ikircimli bir şekilde genç kadını, kendi kötü durumunun doğrudan değil, ancak dolaylı ifade edebildiği gerçekliğini ortaya koyabilmek için bir araç olarak kullanmak olduğunu söyleyebiliriz. Bir diğer ifadeyle, bütün bir ikinci bölümü oluşturan iltifatların esas olarak hep kendisiyle meşgul olan şairin kendi gerçekliğine yenilişini dolaylı olarak yücelten ve aynı zamanda yaşadığı yitimin nedenlerini gizleyerek göstermek için etik değil, estetik nitelikli birer ifadesi olduğunu söylemek mümkündür. Eğer şair sahih olsaydı, olanağı olmasına rağmen kendisinin bilinçli bir şekilde reddederek değersizleştirdiğini ötekinden istemezdi. Bu tarz sahih değil, sahici ifadelerin ardına gizlenmiş sahih olmayan durumların da esaretin birer aç1lımı olduğunu ve onun tarafindan belirlediğini söylemek doğru olur.

Şiirde 1şıdığı kadarıyla esaret, insan varlığını neden tehdit etmektedir? İnsan her şeyden önce bir kimlik değil nelik, yani bir dünya ve durum içinde bulunan bir olanak varlığıdır ve onun varlığının anlamı da en temel insanî olanaklarını yitimselliğine uygun bir açıklıkta yorumlamaktır. Yorumlama, anlam vermeyle değerlemeyi içerdiği için insan, hemen her eylemiyle bir olanak değerlendirmesini gerçekleştirir. Bu bağlamda insanın insan olması, ontolojik antropoloji tarafından işaret edilen bilme, duyma, görme, adama ve aşma gibi en temel olanaklarını değerlendirmesine bağlı olduğunu söyleyebiliriz. Bu en temel insanî olanaklar değerlendirildiğinde özgürlük, belirleyici olmakta ve kendisini gerçekleştirmektedir. Olanakların israf edilip değerlendirilmediği durumlarda ise esaret belirleyici olduğu için şeyleri kapatarak kendisini 
gerçekleştirmektedir. Bütün bir şiire bu bağlamda bakarsak, şairin kendini daha derinden bilme olanağı açılmasına rağmen onun kendi gerçeğini bilmeyi istemek yerine, bilmeyi istemeyen bir tavrı tercih ettiğini görebiliriz. Kendisini bir tavırla gösteren bu kasıtlı bilmeyi istememe durumu ise içinde olunan ancak farkında olunmayan esaret durumunun açılımıdır. Sahih bir olanağın israfi olarak insan varlığını tehdit eden bir unsur olarak ışır.

Bilmeyle tanıma gibi, insanın bir diğer olanağı da değerlerin sesini duymaktır, diyebiliriz. Niteliği ister olumlu ister olumsuz olsun yüksek değerlerin sesinin duyulması veya onların eylemlerle değerlendirilmesi durumunda, insan en azından ötekilerden kendisini ayırabilecek bir kendilik zeminine sahip olabilmektedir. Örneğin herkesin kayıtsızlığıyla belirginleştiği bir zaman diliminde onlardan özgürleşip değerleri yeniden değerlendirmek, sahih bir kendiliğe çok sağlam bir zemin hazırlayabilmektedir. Değerlere sağır kalınması durumunda ise şiirin özellikle son bölümünde de görüldüğü gibi, kayıtsızlık seçilen bir değer olarak bir olanağı kapatabilmektedir. Anımsanacağ 1 gibi şiirin son bölümünde şair, içinde bulunduğu duruma karşı kayıtlı olma ile kayıtsız kalma olanakları arasından ikincisini tercih ederek bir değer olarak özgürlüğün değil, esaretin sesini duyduğunu ortaya koymuştu. Onun bu seçimi ise bir olanağın kapatıldığını bildirirken varllğ̆ tehlikeye atanın da kayıtsızlık olduğunu gün yüzüne çıkarır.

Kendini ve gerçeği bilip aşmak ile çözülen anlam, amaç ve hedefleri yenileyerek onlara adanmak, insanın sayısız olanaklarından bir kaçıdır. Her nerede ve ne zaman olursa olsun bu olanakları, özgürlük gerçekleştirirken esaret ise tek tek kapatır. Bu dikkatle bakıldığında şiirde şairin, yitimle görünür hale gelen kendi gerçeğiyle karşılaştıktan onu aşmak yerine çözüldüğünü, yaşamının anlamını ve amacını kaybettiğini ve boşuna ve beyhude kelimelerinin de resmettiği bir çaresizlik durumunda kaldığını görüyoruz. Şairin birer tercihi de içeren bu eylemleri ise özellikle her şeyin boş, saçma ve "gülünç" olduğuna dair oluşan bir kanıyı, bir tehlike olarak aydınlığa çıkarır. Çoğu zaman farkında olmasak da her günkü basit eylemlerimizde bile zorunlu olarak bir şeyin önü aç1lırken başka bir şeyin ise önü kapanır. Bu noktada şair, aşıp geçme ve yitirdiği şeyleri geriye çağırma ile kendisini yeniden bulma olanağını, yani özgürlüğü kapatarak tehlikenin kapatıcı nitelikli bu ruh halinin bizzat kendisi olduğunu dramatize ederek göstermiş olur şiirinde.

İnsan üç boyutlu zaman içinde yaşayan bir varlıktır ve zamanın bu üç boyutu da kendi içinde bütünlüğü kurulduğunda, yani geçmiş şimdiye, şimdi geleceğe bağlanabildiğinde tarihsellik sahih olarak gerçekleştirilebilen bir insan olanağı olmaktadır. Bu olanak, ölüme saplı kalındığında, yani geçmişle he- 
saplaşıcı bir ilişki kurulmadığında, insanı üç ayrı yerinden kendisine çekerek parçalayan bir unsura dönüşebilmektedir. Bir diğer ifadeyle sahih tarihsellik, insanın bir olanağıdır. Bu olanak, değişerek devam edildiğinde kendisini açarken o tür bir devamlılığa dair inancın yitirilmesi durumunda ise sadece kendisini değil, içten bağlı olduğu diğer pek çok olanağı da kapatmaktadır. Müsrifliği ile dikkati çeken şiirin anlatıcısının bu bağlamda sahih tarihselliğini kurma olanağ karşısına çıkmasına rağmen diğerleri gibi bunu da kasıtlı olarak harcayıp israf ettiğini söylemek olanaklıdır. Bir diğer ifadeyle karş1laşma hadisesiyle kendisini gösteren gerçeklik, şaire bütün bir geçmişi anlamlandırıp aşarak onu geleceğe bağlama olanağı sunar. Ne var ki şair aldığı olumsuz tavırla zamanın üç boyutu arasındaki bu parçalanmayı aşma olanağını bilinçli olarak kapatır.

Yukarıda söylediğimiz hususların yanı başında insan sahih isteme, önceden görme ve inanma gibi olanaklarını da değerlemek zorunda olan bir varlıktır. Diğer durumlarda olduğu gibi bu olanakların gerçekleştirilmesinde de özgürlük belirleyici olurken bunlar değerlendirilmediğinde ise esaret öne çıkmaktadır varlık olarak. Bu dikkatle şiire bakarsak, yine anlatıcı şairin, yaptığ seçimle birlikte kendisiyle karşılaştıktan ve eş zamanlı olarak yitim deneyimini yaşadıktan sonra bütün bu insanî olanaklarını, ölüme esir olduğu için kuruttuğunu, dolayısıyla da onların yeşermesine olanak sağlamadığını görebiliriz. Kurutmak, sahih isteme, tavır alma ve inanmanın yokluğunu, yeşertmek ise onların varlığını imler. Bunun için de kurutucu olanın esaret, dolayısıyla ölüm; yeşertici olanın ise özgürlük, dolayısıyla da yaşam olduğunu söyleyebiliriz.

\section{Sonuç}

Bu yazıda ele alınan Zaman Kırıntıları isimli şiiri, insan varlığını tehdit eden unsuru, içinde olunan ancak farkında olunmayan bir durum olan esaret olarak görünüşe çıkaran bir şiirdir. Şiirde imlenen ve aynı zamanda bir durumun ismi de olan esaret, özgürlük olarak isimlendirdiğimiz insan olma olanağının ölüm içgüdüsünün belirlemesinde değerlendirilişi, dolayısıyla da değerlendirilemeyişi demektir. Her haliyle bir değerin harcanışını işaret eden özgür olmayış, psikanalizin vurguladığı olanak açıcı ve yeşertici olan yaşam içgüdüsünün değil, bilakis olanakları kapatıcı ve kurutucu olan ölümün belirleyici olmasıdır. Eşleştirerek tanımladığımız bir durum olarak esaret, adı geçen şiirde, ömrünün son dönemine girdiğini bilen şairin bir genç kadınla kurduğu ilişki dolayısıyla karşılaştığı olanaklar arasından seçim yaparak yaşadığı bir yitim deneyimi ile bu hadise karşısında aldığı tavırda ifadesini bulmuştur. Bir 
bütün olarak düşünüldüğünde bu şiirde, içinde olunan ancak farkında olunmayan bir durum olarak esaretin bilme, duyma, görme, aşıp geçme, adama, inanma ve varolma gibi en temel olanakları kapatarak insan varlığını tehdit eden bir unsur olarak öne çıkarıldığını söylemek mümkündür.

Ahmet Hamdi Tanpınar, "Bence insan, her şeyden önce mesuliyet duygusudur. İnsan olmak itibarıyla bütün kâinattan mesulüz (Tanpınar 2016: 120121) der. Bu bağlamda şairini bir dramı dramatize ederek gösteren insan seviyesine çıkaran, dolayısıyla neyse onu olduğu gibi görünür kılarak edebiyat tarihimize önemli bir katkıda bulunan bu şiir gibi Tanpınar'ın diğer edebî metinlerinin de yeni okumalara açık olduğunu söylemek mümkündür.

\section{Kaynaklar}

Çankaya, Hüsamettin (2012). "Devletsiz Düşünce”, Flanör Düşünce, Derleyen: Hüseyin Köse, İstanbul: Ayrıntı Yayınları.

Enginün, İnci - Kerman, Zeynep (2008). Günlüklerin Işı̆̆ında Tanpınar'la Başbaşa, İstanbul: Dergâh Yayınları.

Freud, Sigmund (2016). Haz ilkesinin Ötesinde-Ben ve İd-, Çev. Ali Nahit Babaoğlu, İstanbul: Metis Yayınları.

Heidegger, Martin (2008). Varlık ve Zaman, Çev. Kaan H. Ökten, İstanbul: Agora Kitaplığ1.

Kurtar, Senem (2014). Heidegger ve Poetik Düșünme, Ankara: Pharmakon Yayınevi.

Mengüşoğlu, Takiyettin (1988). “Özgür Bir Varlık Olarak İnsan”, İnsan Felsefesi, İstanbul: Remzi Kitabevi, s.129-139.

Okay, Orhan (2010). Bir Hülya Adamının Romanı Abmet Hamdi Tanpınar, İstanbul: Dergâh Yayınları.

Sunat, Halûk (2004). Boşluğa Açılan Kapı-Ahmet Hamdi Tanpınar ve Yapıtlarına Psikanalist Duyarlıklı Bir Bakış-, İstanbul: Bağlam Yayınları.

Tanpınar, Ahmet Hamdi (2015). Bütün Şiirleri, Haz. İnci Enginün, İstanbul: Dergâh Yayınları.

(2016). Hep Aym Boşluk-Denemeler Mektuplar Röportajlar-, Haz. Erol Gökşen, İstanbul: Dergâh Yayınları.

Kaufmann, Walter (2009). İnsanı Anlamak II -Nietzsche ile Heidegger-, İstanbul: İdea Yayınları. 


\section{Sonnotlar}

1 İncelemede metnin son baskısı esas alınmıştır. Bakınız: (Tanpınar 2015: 73-78).

2 Ölüm ve yaşam içgüdüsü ile haz ve gerçeklik ilkeleri hakkında bilgi için bakını: (Freud 2016).

3 Orhan Okay, Ahmet Hamdi Tanpınar' 1 "hayatının hemen her safhasında, her hadise ve sanat eseri karşısında daima "kendine rastlayan", daha sonra kendisiyle didişen insan" olarak niteler. Onun eserlerinde kendini tanımanın ilk adımı demek olan kendine rastlamak ile kendisiyle karşılaşmanın önemli bir laytmotif oluşturduğunu belirtir (Okay 2010: 67-77).

4 Şair, şiirin özellikle birinci ve üçüncü bölümlerinde biz zamirleriyle konuşarak sanki bu deneyim sadece kendisinin değil de ortak bir deneyimmiş gibi yapar ve kendisini kandırır. Oysa gizlenmesi mümkün olmayan bu deneyim, sadece onundur.

5 Ayrıntılı bilgi için bakınız: (Enginün-Kerman 2008). 
